\title{
Evaluation of fiscal space for health in Bolivia*
}

\author{
Mauricio Matus-López, ${ }^{1}$ Desiderio Cansino Pozo, ${ }^{2}$ Camilo Cid Pedraza, ${ }^{3}$ Werner Valdés Romero ${ }^{4}$
}

Suggested citation (original article) Matus-López M, Cansino Pozo D, Cid Pedraza C, Valdés Romero W. Evaluación del espacio fiscal para salud en Bolivia. Rev Panam Salud Publica. 2018;42:e4. https://doi.org/10.26633/RPSP.2018.4

ABSTRACT Objective. To assess, from a technical and political standpoint, the capacity of Bolivia to generate fiscal space for health that allows the country to sustain progress and fulfill the commitment of a public expenditure in health of $6 \%$ of gross domestic product.

Methods. A review was conducted of the international evidence on fiscal space and how it is measured. The technical analysis was developed through statistics and official reports from multiple national and international secondary sources. The political and social analysis was carried out through 20 interviews with representatives of organizations and institutions.

Results. There is capacity to create fiscal space in health for Bolivia. The three sources with the greatest technical and political feasibility are: economic growth linked to a commitment to reprioritize public spending on health; improvements in the internal sources of revenue through the reduction of informal work; and reduction of tax expenditures. External financing and an increase of Social Security contributions are less feasible.

Conclusions. Bolivia is able to achieve a public health spending of $6 \%$ of gross domestic product. The timing to achieve this target depends on maintaining the prioritization of spending in the sector, with social and political consensus and within a framework of economic growth and stability.

Keywords Healthcare financing; financial policy; universal coverage; health resources; Bolivia.

In 2016, Bolivia had a population of 10.9 million. From 2010 to 2014 , its gross domestic product (GDP) grew at an average rate of 5.3\% annually, reaching US\$3,124.10 per capita. This growth, combined with social policies, has led to an improvement in nearly all of Bolivia's indicators. Between 2006 and 2014, the poverty rate fell from $59.9 \%$ to $39.3 \%$ of the population and extreme poverty, from $37.7 \%$ to $17.3 \%$, while life expectancy increased by more than 10 years in just two decades (1).

Notwithstanding this progress, the health sector still has unresolved problems. Although Bolivia is one of the countries with higher public expenditure in health (PHE) $(4.6 \%$ of GDP in 2014), its expenditure per capita is only US\$ 142.27. Thus, two out of three Bolivians still do not have health insurance (61.2\%). Moreover, those who do are distributed across a fragmented system of over 20 public and private insurance providers (1-3).

\footnotetext{
* Official English translation from the original Spanish manuscript made by the Pan American Health Organization. In case of discrepancy, the original version (Spanish) shall prevail.

1 Departamento de economía, métodos cuantitativos e historia económica, Universidad Pablo de Olavide, Sevilla, Spain. $\square$ Mauricio Matus-López, mmatlop@ upo.es
}

In 2014, Bolivia, like the rest of the member countries of the Pan American Health Organization, agreed to raise its PHE to $6 \%$ of GDP (4), a value that would substantially reduce the incidence of catastrophic household health expenditures (5) and facilitate progress toward universal health. To meet this target, it must be determined whether the country has the capacity to create the fiscal space to finance it.

Fiscal space (FS) is defined as additional budgetary resources to meet a country development goal without jeopardizing its economic and financial stability or solvency. There are four main sources of FS: economic growth, reprioritization of budget expenditure, tax revenues, and efficiency in public expenditure (6-10).

Specific studies on FS for health have been conducted for some 30 countries, yielding three conclusions: a) each case is

\footnotetext{
2 Doctoral student, Universidad Pablo de Olavide, Sevilla, Spain 3 Pan American Health Organization, United States of America. 4 External consultant, La Paz, Bolivia.
} 
different; there are no general rules and the particular characteristics of each country determine the results; b) the sources of FS must be diversified; and c) it is advisable for the sources of FS to be endogenous $(7,10-13)$. The objective of this study is to evaluate the sources for the creation of FS in Bolivia and estimate the existing margin for meeting this expenditure target.

\section{MATERIALS AND METHODS}

A quantitative and qualitative methodology was used.

The sources of fiscal space were identified through a review of the scientific literature in the PubMed, Web of Science, Scopus, and SciELO databases, in addition to reports and working papers of the World Health Organization (WHO) (14), the World Bank (WB) (15), and the International Labour Organization (ILO) (16).

Secondary information from domestic and international sources was used for the technical analysis. The domestic sources included the National Statistics Institute (INE) (1), the Central Bank of Bolivia (BCB) (17), the Ministry of Economy and Finance (women of reproductive age) (18-20), the Ministry of Health (21), and the National Health Insurance Institute (INASES) (3). The international sources were the databases of WHO (2), the World Bank (22), the International Monetary Fund (IMF) (23), and the Organization for Economic Cooperation and Development (OECD) (24).

The sociopolitical analysis involved 20 interviews (Annex) and surveys of institutional, political, and societal representatives. This included the Ministry of Health, women of reproductive age, the Ministry of Development Planning, the Social and Economic Policy Analysis Unit, the National Health Fund, representatives of the National Unity Front (UN) and the Socialist Movement (MAS) in the Legislative Assembly, the Medical Association, the United Union Workers Confederation, national foundations and experts, etc. The sample was designed by a local expert, who conducted the field work between June and July 2016. Eighty percent of it ( $n=16)$ consisted of face-to-face interviews about 40 minutes long with a total of 20 open-ended and closed questions. The remaining $20 \%$ of interviewees $(n=4)$ were sent a questionnaire with the same questions. This was the case for the UN and MAS representatives. In the closed questions, a Lickert scale was used to rate the degree of acceptance of/opposition to different measures and sources of financing, with 1 indicating total acceptance and 10, total opposition.

\section{RESULTS}

\section{Macroeconomic conditions of stable growth}

Using IMF 2015-2020 growth projections, the evolution of PHE was estimated for three scenarios: optimistic, neutral, and pessimistic. Based on the international literature, the projection was made through PHE elasticities with respect to GDP (11, 13). In the optimistic scenario, it was assumed that the efforts of recent years would continue in the future. Therefore, the average for 2004-2014 was used. In the neutral scenario, the two highest values for the same period were eliminated from the series. Finally, in the pessimistic scenario, the complete series for 1995-2014, excluding outlier values, was used, which assumes the incorporation of low values from the previous decade. The elasticities were 1.63 for the optimistic scenario, 1.25 for the neutral scenario, and 1.16 for the pessimistic scenario, yielding increases of up to 0.7 points, 0.3 points, and 0.2 points of GDP, respectively (Table 1 ).

The sociopolitical analysis showed an average acceptance of this source among interviewees of 7 on a scale of 10 .

\section{Reprioritization of health expenditure}

In the lower-middle-income countries, reprioritization of PHE is conditional to the risk of creating new problems financing other important needs such as education or poverty assistance (6).

The data show that PHE as a percentage of total public expenditure (PE) was $9.7 \%$ in 2013, far above the $6.2 \%$ of the lower-middle-income countries (2). Nonetheless, $9.7 \%$ still is below the level of the Latin America and Caribbean region, since almost half the countries in that region have percentages above $15 \%$.

Creating FS through the reprioritization of budgets cannot be accomplished in a single stroke but must be done incrementally (11), with emphasis more on distributing new resources than on reorganizing historical ones.

The assumption in the scenarios analyzed in this study was that the incremental budget is distributed in a manner similar to that of Latin America. That is, that health expenditure is the result of applying $9.7 \%$ to the total PE of the previous year, plus $15.1 \%$ to the increase in the total expenditure of the current year.

Under a first scenario, which is unlikely, the $15.1 \%$ would be applied immediately. Under a second scenario, which is more realistic but also optimistic, it would be applied gradually. Thus, the reprioritization of expenditure can generate FS of 0.53 and 0.3 points of GDP, respectively. This confirms the international evidence that this source for the creation of FS is limited by its inflexible structure and the fact that, even with increments, the decision to reduce the weight of one sector to benefit another is problematic from a political standpoint.

\section{New sources of revenue}

Changes in general taxes. The national data show that tax revenues have continued to grow in the past decade $(18,19)$. In 2013 , they accounted for $27.6 \%$ of GDP, 6.3 points higher than the regional figure $(21.3 \%)$ and a similar distance from that of the OECD countries (34.1\%) (24).

Tax revenues are comprised chiefly of taxes on corporate profits (IUE), with $27.4 \%$ of the total; followed by the domestic value-added tax (VAT), with 23.5\%; the external VAT, with $22.3 \%$; and the complementary VAT with $1 \%$, together accounting for $46.8 \%$ of the revenue. Specific taxes on consumption account for $6.1 \%$ (19).

Depending on the composition, the difference between Bolivia and the affluent countries is due mainly to direct taxes. In the OECD countries, these revenues account for $11.4 \%$ of GDP, while in Latin America and the Caribbean, the figure is only 5.5\%, and in Bolivia, just 3.9\% (24).

This issue is very important, since the difference between one type of tax and another is not neutral in terms of health: direct and progressive taxes make it possible to promote universal coverage without jeopardizing health outcomes (25-27). 
TABLE 1. Fiscal space for health (projection based on macroeconomic conditions), Bolivia, 2012-2021

\begin{tabular}{|c|c|c|c|c|c|c|c|c|c|c|}
\hline & 2012 & 2013 & 2014 & 2015 & 2016 & 2017 & 2018 & 2019 & 2020 & 2021 \\
\hline Real variation in GDPa & 5.12 & 6.8 & 5.46 & 4.80 & 5.0 & 4.0 & 4.25 & 3.50 & 3.50 & 3.50 \\
\hline GDP (millions) $)^{b}$ & 193191 & 206321 & 217587 & 228031 & 239432 & 249010 & 259592 & 268679 & 278082 & 287815 \\
\hline Population (millions) & 10.24 & 10.4 & 10.57 & 10.74 & 10.9 & 11.07 & 11.24 & 11.4 & 11.56 & 11.73 \\
\hline \multicolumn{11}{|l|}{ Optimistic scenario } \\
\hline $\begin{array}{l}\text { Public expenditure in health } \\
\text { (millions) }^{\mathrm{b}}\end{array}$ & 7288 & 8745 & 9934 & 10530 & 11386 & 12128 & 12967 & 13706 & 14487 & 15312 \\
\hline $\begin{array}{l}\text { Public expenditure in health } \\
\text { per capita }^{\mathrm{b}}\end{array}$ & 712 & 841 & 940 & 980 & 1044 & 1096 & 1154 & 1202 & 1253 & 1305 \\
\hline \multicolumn{11}{|l|}{ Neutral scenario } \\
\hline $\begin{array}{l}\text { Public expenditure in health } \\
\text { (millions) }^{\mathrm{b}}\end{array}$ & 7288 & 8745 & 9934 & 10530 & 11188 & 11747 & 12371 & 12913 & 13477 & 14067 \\
\hline $\begin{array}{l}\text { Public expenditure in health } \\
\text { (\% of GDP) }\end{array}$ & $3.8 \%$ & $4.2 \%$ & $4.6 \%$ & $4.6 \%$ & $4.7 \%$ & $4.7 \%$ & $4.8 \%$ & $4.8 \%$ & $4.8 \%$ & $4.9 \%$ \\
\hline 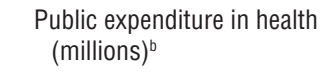 & 7288 & 8745 & 9934 & 10530 & 11140 & 11657 & 12231 & 12727 & 13243 & 13781 \\
\hline $\begin{array}{l}\text { Public expenditure in health } \\
\text { ( } \% \text { of GDP) }\end{array}$ & $3.8 \%$ & $4.2 \%$ & $4.6 \%$ & $4.6 \%$ & $4.7 \%$ & $4.7 \%$ & $4.7 \%$ & $4.7 \%$ & $4.8 \%$ & $4.8 \%$ \\
\hline $\begin{array}{l}\text { Public expenditure in health } \\
\text { per capita }^{\mathrm{b}}\end{array}$ & 712 & 841 & 940 & 980 & 1022 & 1053 & 1089 & 1116 & 1145 & 1175 \\
\hline
\end{tabular}

Without ignoring the country's enormous advantage of being able to finance part of its public expenditure through its natural resources, there is margin for revenues from direct taxes on profits.

An attainable goal could be to reduce the gap between Bolivia and the countries of the region in taxes on income and profits, by raising these taxes to $4.3 \%$ of GDP. Another, more optimistic, scenario would be to gradually equalize these revenues so that by 2021 they reach $4.7 \%$ of GDP, halving the gap.

The FS created in each scenario could average 0.4 and 0.8 points of GDP, respectively. Furthermore, the sociopolitical analysis showed an average acceptance of 8 on a scale of 10 .

Health-specific taxes on goods. This refers basically to three types of taxes: on tobacco, on alcoholic beverages, and on food with a high sugar or fat content. These taxes are called "sin taxes" or "earmarked taxes" in the literature because they have a dual purpose: increasing tax revenues that can be allocated directly to health and discouraging the consumption of harmful products, thereby reducing future health expenditure.

With regard to most alcoholic beverages, except beer, specific taxes on consumption have remained constant or fallen in real terms. Given their elasticities (28) and current tax rates, a tax increase would not have a significant impact on FS, but would have positive effects in reducing expenditures for the treatment of related diseases.

With regard to tobacco, Bolivia has one of the lowest tax rates in Latin America and one that is far from the levels of France, Spain, or Chile, meaning that there is margin for creating FS through this source.
Tobacco tax revenues totaled Bs 121.9 million in 2013 (14), or $8.9 \%$ of the total revenue from specific domestic taxes, $0.2 \%$ of tax revenues, and only $0.05 \%$ of GDP. Assuming the indicated elasticity of -0.85 (29) and a $20 \%$ increase in the price, the revenue generated would create FS of $2 \%$ of the taxes. Although this percentage is low in terms of GDP, it would mean an additional Bs 2.4 million for the budget.

It should be noted, that a potential effect of this measure would be incentives to sell these goods on the black market; however, there are no estimates of the price elasticity of this phenomenon in Bolivia. In the sociopolitical analysis, raising the tax on tobacco and domestically produced alcoholic beverages enjoyed a moderate level of support: 7 on a scale of 10 . Support for taxes on imported beverages was higher, at 9 on a scale of 10 . The favorable opinions were based on the economic and social benefits of reducing the consumption of these products.

Taxes on natural resources. In Bolivia, taxes on natural resources are one of the main sources of financing for public expenditure. The direct tax on fossil fuels (IDH) alone accounted for $27 \%$ of total tax revenues.

The IDH is a clear source of FS with margin to continue generating resources. However, their flow depends on international variations in raw material prices.

With regard to FS for health, the resources from fossil fuels can help meet the target of PHE of $6 \%$ of GDP. In 2014, the IDH alone reached $6.8 \%$ of GDP. Earmarking an increase of less than $10 \%$ of the revenues from this tax would be enough to increase PHE by more than half a point of GDP and put the country 
very near the target. It all depends on political feasibility and the impact that a decision of this type would have on business decisions concerning production, a question that is beyond this analysis.

Contributions to social security. Social security contributions in the country are very low, representing just $1.4 \%$ of GDP, while the average for Latin America is 3.8\% and for the OECD countries, $9 \%$.

There are two direct explanations for this low figure. The first is the political decision to have a system in which employers shoulder the entire burden of the contributions, without compulsory contributions from workers, in contrast to the majority of countries with social security systems that finance health.

The second explanation lies in the high level of informality in the labor market, which stands at around $75 \%(30,16)$. An effort involving a 10-point reduction in informality could increase enrollees by some $15.6 \%$ to $24.4 \%$ (i.e., from 0.22 to 0.34 points of GDP) without altering premium rates.

Changes in premium rates are a virtual non-starter. The interviewees were strongly opposed to this measure, with average support of just 2 on a scale of 10 .

Thus, the margins for FS through contributions to social security can be wide if informality is reduced and a solidarity-based contribution system is introduced (30) but raising premium rates does not appear to be feasible.

\section{Increasing efficiency in tax collection and expenditure}

This section analyzes two types of efficiency, as indicated in the PAHO analytical framework (9): tax expenditures as efficiency in collection; and efficiency in health system management.

Efficiency in collection: tax expenditure. Tax expenditure consists of all exemptions from the general tax regulations to meet certain strategic objectives for the economy. According to the Ministry of Economy and Public Finance (MEFP), tax expenditure accounted for 1.3\% of GDP in 2013, which implies a $17.7 \%$ increase with respect to 2011 , but a reduction with respect to $2005(18,32,33)$.

The FS generated by eliminating tax expenditures would come to $1.3 \%$ of GDP. However, it is important to consider what part of this tax expenditure should be retained or eliminated.

The MEFP mentions two issues for consideration (20). The first is exemptions from the additional aliquot on the corporate income tax (IUE) of miners' cooperatives, which taxes windfall profits and (even though these are cooperatives) also taxes the use of a non-renewable resource. The second is the limited effect of incentives created for the economic development of some regions, which made the tax regulations more complicated.

Finally, the export industry, responsible for almost half of the tax expenditures, should be analyzed in depth, especially the part that yields limited value added.

Following MEFP guidelines, and through a $10 \%$ reduction in export tax expenditures, a margin of $0.07 \%$ to $0.1 \%$ of GDP could be generated.
From the sociopolitical analysis, reducing tax expenditures enjoys a high degree of acceptance. On a scale of 1 to 10 , the interviewees averaged 8 . Nevertheless, the negotiating powers of the agents vary widely, and in this case, are very important.

Efficiency in management: health expenditure. Efficiency in PHE is a source in nearly all the studies on FS. In practice, estimating an efficiency indicator is a complex undertaking, and its evaluation ultimately involves comparisons between countries or national analyses confined to certain services or regions.

The evidence shows that greater PHE improves health indicators and is more effective when its resources derive from direct taxes or shared risk mechanisms $(25,34)$.

Therefore, a simple and direct calculation is to compare PE and the infant mortality rate for a series of countries around the world. According to this calculation, Bolivia has mortality rates similar to those of countries with similar income levels, meaning that its performance in health can be interpreted as normal given the public resources utilized (2).

In an econometric analysis of data from 165 countries, Bolivia ranked 28th among the 45 lower-middle-income countries. This is somewhat above the average for its group, although below that of the Latin American countries in that group (35).

A third analysis considers a concave production-possibility curve. That is, the higher the expenditure, the lower the possibility of marginal productivity gains (36). In this case, Bolivia ranked 62nd out of 191 countries. Given the aforementioned evidence, even with a $5 \%$ increase in efficiency, the FS generated would be approximately $0.1 \%$ of GDP.

On the other hand, efficiency also increases with the optimization of financing and insurance models. The presence of 20 health insurance programs in the country, side by side with a high percentage of uninsured population, is manifestly a sign of inefficiency (3).

Finally, the development and strengthening of a health system organized as integrated health care delivery networks and solidly based on the first level of care can yield significant efficiency gains. This can be supported with financing policies that promote the implementation of adequate payment systems.

Increasing the efficiency of public expenditure enjoys average support of 9 on a scale of 10 .

\section{External financing}

Two sources of FS are analyzed: public debt and international donations and cooperation.

Public debt. Bolivia is an economy whose public debt plummeted from $63.5 \%$ of GDP in 2003 to $14.5 \%$ in 2011 . This puts it in a good position to meet its financial commitments and have borrowing capacity. However, expanding FS in health through debt would translate over time into an advance on future resources with an interest cost.

From the sociopolitical analysis, there is little acceptance of debt as a source of FS, especially if the resources are to be allocated to wages. However, the degree of acceptance increases when the resources are to be invested in sector infrastructure, such as new hospitals. 
TABLE 2. Fiscal space for health (source, technical feasibility, political/social feasibility and evaluation), Bolivia, 2015-2020

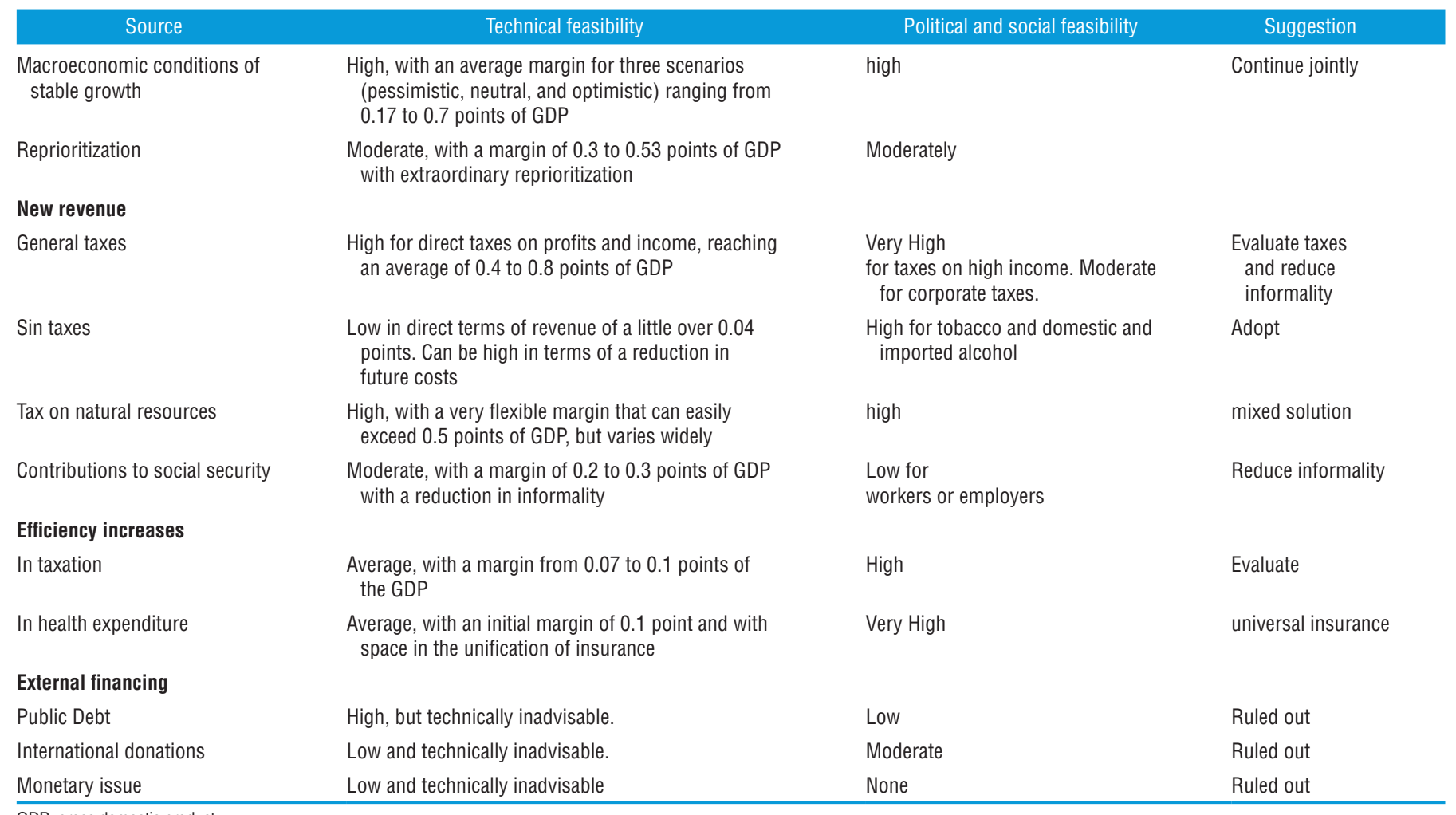

International donations and cooperation. As in other countries, the uncertainty and variability of donation and cooperation flows make this source of FS creation inadvisable $(7,11,13)$.

\section{DISCUSSION}

The review of the international evidence shows that in the majority of the cases studied there is capacity to create FS. The results for Bolivia are similar (Table 2). The country has the possibility of increasing PHE without jeopardizing economic sustainability.

In the technical sphere, the results are consistent with the international evidence. Economic growth is one of the sources that garners greater political and social consensus and represents a large margin for revenue. If this source continues its upward trend while maintaining prioritization of $\mathrm{PE}$, it will enable Bolivia to meet the target of PHE of $6 \%$ of GDP. Reprioritization of $\mathrm{PE}$ can reduce the time it will take to meet this target.

Although fossil fuels are an important source of State revenue, the generation of new revenue through direct taxes, health taxes, or the reduction of labor informality should not be ignored, the latter being one of the sources farthest from the influence of the health sector.

The insurance system is marked by inefficiencies, and while the public system shows progress in access, three out of five Bolivians are not covered by insurance, and economies of scale are lost in a maze of microsystems that generates inequalities in a sensitive area like health.
Four limitations of the study should be noted. First, its calculations do not quantify the economic cost of universal coverage but only the possibilities of financing PHE. Second, the number of interviews and their methodology do not indicate the power of the agents but merely provide information on the degree of acceptance of or opposition to the sources of financing. Third, there is no assessment of the timeframes in which the FS could be implemented. Finally, since it is a study on financing, it does not analyze the distribution of expenditure by level or territory or its distributive impact.

\section{CONCLUSIONS}

Although the challenge of reaching PHE of $6 \%$ of GDP requires a substantial effort, it is achievable. The sources of financing show margins not only through economic growth but through the improvement of tax collection and greater system efficiency. Finally, people and sector organizational processes will be essential for these resources to translate into more equitable access to health in Bolivia.

Conflicts of interest. None declared by the authors.

Financing. This study was financed by the Pan American Health Organization.

Disclaimer. The opinions expressed in this manuscript are the responsibility of the authors and do not necessarily reflect the opinion or policy of the RPSP/PAJPH and/or of PAHO. 


\section{REFERENCES}

1. Instituto Nacional de Estadística de Bolivia. Información estadística. Available from: http:/ / www.ine.gob.bo Cited 2016 June 1.

2. World Health Organization. Global Health Observatory Data Repository. Available from: http://bit.ly/1Kv0EfJ Cited 2016 June 20.

3. Instituto Nacional de Seguros de Salud de Bolivia. Anuario estadístico 2014. Available from: http://inases.gob.bo/normas-2 /anuario-estadistico/ Cited 2016 June 10.

4. Pan American Health Organization. Resolution CD53.R14. Strategy for Universal Access to Health and Universal Health Coverage. 53rd Directing Council, 66th Session of the Regional Committee of WHO for the Americas. Washington, DC, USA, 2014 September 29 - October 3. Available from: https://www.paho.org/hq/dmdocu ments/2014/CD53-R14-e.pdf

5. Ke X, Saksena P, Jowett M, Indikadahena Ch, Kutzin J, Evans D. Exploring the thresholds of health expenditure for protection against financial risk. World Health Report, Background Paper, 2010;19. Available from: http://www.who.int/healthsystems/topics/financing/healthreport/19THE-thresv2.pdf?ua=1

6. Heller P. Back to Basics. Fiscal space: what it is and how to get it. Finance and Development, International Monetary Fund 2005;42(2). Available from: http://bit.ly/1LNX528

7. Tandon A, Cashin C. Assessing public expenditure on health from a fiscal space perspective. Washington, DC: World Bank; 2010. Available from: http://bit.ly/1Pt6AHl

8. Ostry JD, Ghosh AR, Kim JI, Qureshi MS. Fiscal space. IMF Staff Position Paper. 2010;SPN/10/11,1. Available from: https://www .imf.org/external/pubs/ft/spn/2010/spn1011.pdf

9. Pan American Health Organization (PAHO). Fiscal space for increasing health priority in public spending in the Americas. Washington, DC: PAHO/WHO; 2015. Available from: https://www.paho.org /hq/dmdocuments/2015/fiscal-space-americas-15.pdf

10. Barroy H, Sparkes S, Dale E. Assessing fiscal space for health expansion in low and middle-income countries: A review of the evidence. Health Financing Working Paper. 2016;3. Available from: http:// apps.who.int/iris/bitstream/10665/251904/1/WHO-HIS-HGF -HFWorkingPaper-16.3-eng.pdf?ua $=1$

11. Matus-López M, Prieto L, Cid C. Espacio fiscal para salud en Perú. Rev Panam Salud Pública. 2016;4(1):64-9.

12. Durán-Valverde F, Pacheco JF. Fiscal space and the extension of social protection. Lessons learnt from developing countries. ESS Paper Series SECSOC. 2012;33. Available from: http://bit.ly /1iM3tAd

13. Sharma J. An assessment of fiscal space for health in Bhutan: Fiscal space for health in Bhutan. Int J Health Plann Manage. 2015. doi:10.1002/hpm.2295

14. World Health Organization (WHO). WHO report on the global tobacco epidemic. Raising taxes on tobacco. Luxemburg: WHO; 2016. Available from: http:/ / bit.ly/1HdHZRY

15. World Bank. Purchasing power parities and the real size of world economies. A comprehensive report of the 2011 International Comparison Program. Washington, DC: World Bank; 2016. doi: 10.1596 /978-1-4648-0329-1

16. International Labour Organization (ILO). Thematic Labour Overview. Transition to formality in Latin America and the Caribbean; 2014. Available from: https://www.ilo.org/wcmsp5/groups/public/--americas /---ro-lima/documents/publication/wcms_314469.pdf

17. Banco Central de Bolivia (BCB). Boletines estadísticos 2004-2015. 2016. Available from: https://www.bcb.gob.bo/?q=pub_boletin -estadistico

18. Ministerio de Economía y Finanzas Públicas de Bolivia. Tributación sobre Industria Extractiva en Bolivia. Conferencia "Tributación de las industrias extractivas en la Región Andina". Lima: Viceministerio de Política Tributaria; 2014. Available from: ht-tps://www.imf .org/external/spanish/np/seminars/2014/natres/pdf/rios3.pdf

19. Ministerio de Economía y Finanzas Públicas de Bolivia. Boletín de ingresos y gastos tributarios. 2016:5. Available from: http://
medios.economiayfinanzas.gob.bo/VPT/documentos/Boletines_ Ingresos_Tributa-rios/BIyGT_Nro_5.pdf

20. Ministerio de Economía y Finanzas Públicas de Bolivia. Política Tributaria. 2016. Available from: http://www.economiayfi-nanzas .gob.bo/viceministerio-de-politica-tributaria.html

21. Ministerio de Salud de Bolivia. Programas de salud. 2016. Available from: https: / www.minsalud.gob.bo/programas-de-salud

22. World Bank. World Development Indicators. 2016. [Internet]. Available from: http://data.worldbank.org/data-cata-log /world-development-indicators Cited 1 de junio de 2016.

23. International Monetary Fund. World Economic Outlook Database. 2016. [Internet] Available from: http://www.imf.org/external /pubs/ft/weo/2016/01/weodata/index.aspx Cited 2016 May 1.

24. Organisation for Economic Co-operation and Development (OECD), Economic Commission for Latin America and the Caribbean (ECLAC), Inter-American Center of Tax Administrators (CIAT), Inter-American Development Bank (IDB). Revenue statistics in Latin America and the Caribbean. Paris: OECD Publishing; 2015. doi:10.1787/rev_lat-2015-en-fr.

25. Moreno-Serra R, Smith PC. Does progress towards universal health coverage improve population health? Lancet. 2012; 380(9845):91723. doi: 10.1016/S0140-6736 (12)61039-3.

26. Reeves A, Gourtsoyannis Y, Basu S. Financing universal health coverage-effects of alternative tax structures on public health systems: cross-national modelling in 89 low-income and middle-income countries. Lancet. 2015;386(9990):274-80. doi: 10.1016/ S0140-6736(15)60574-8.

27. Yates R. Universal health coverage: Progressive taxes are key. Lancet. 2015; 386(9990):227-9. doi:10.1016/S0140-6736 (15)60868-6.

28. Wagenaar AC, Salois MJ, Komro KA. Effects of beverage alcohol price and tax levels on drinking: a meta-analysis of 1003 estimates from 112 studies. Addiction. 2009;104:179-90.

29. Alcaráz V. Economía del Control del Tabaco en los Países del Mercosur y Estados Asociados: Bolivia, Organización Panamericana de la Salud, 2006. Available from: http://iris.paho.org/xmlui /handle/123456789/2810

30. Vargas M, Garriga S. Explaining inequality and poverty reduction in Bolivia. IMF Working Paper. 2015;WP/15/265. Available from: https://www.imf.org/external/pubs/ft/wp/2015/wp15265.pdf

31. Titelman D, Cetrángolo O, Acosta OL. Universal health coverage in Latin American countries: How to improve solidarity based schemes. Lancet. 2015;385(9975): 1359-63. doi:10.1016/S0140-6736(14)61780-3

32. Villela L, Lemgruber A, Jorratt M. Gastos tributarios: la reforma pendiente. Trimestre Fiscal. 2010;92:79-119. Available from: http:// bit.ly/1WiDGxM

33. Trigueros MP. Gastos tributarios en América Latina: 2008-2012. Centro Interamericano de Administraciones Tributarias CIAT. 2014 Available from: http:// www.ciat.org/index.php/es/productos -y-servicios/publicaciones/documentos-de-trabajo/3582-dt-02 -2014-gastostributarios-en-america-latina-2008-2012.html

34. Bokhari FAS, Gai Y, Gottret P. Government health expenditures and health outcomes. Health Econ. 2007;16(3):257-73. doi: 10.1002/ hec. 1157

35. González E, Cárcaba A, Ventura J. Value efficiency analysis of health systems: Does public financing play a role? J Public Health. 2010;18(4):337-50. doi:10.1007/ s10389-009-0311-4.

36. Kumbhakar SC. Efficiency and productivity of world health systems: where does your country stand? Appl Econ. 2010; 42(13):1641-59. doi:10.1080/00036840701721588.

Manuscript received on 24 May 2017. Accepted for publication, after review, on 17 July 2017. 


\section{Evaluación del espacio fiscal para salud en Bolivia}

RESUMEN Objetivo. Evaluar desde los puntos de vista técnico y político la capacidad de Bolivia para generar espacio fiscal para salud que le permita sostener los avances y cumplir el compromiso de un gasto público en salud de $6 \%$ del producto interno bruto (PIB).

Métodos. Se realizó una revisión de la evidencia internacional sobre espacio fiscal y sus mediciones. El análisis técnico se desarrolló a través del uso de estadísticas e informes oficiales de múltiples fuentes secundarias nacionales e internacionales. El análisis político y social se llevó a cabo mediante 20 entrevistas a representantes de organismos e instituciones.

Resultados. Existe capacidad para crear espacio fiscal en salud para Bolivia. Las fuentes con mayor factibilidad técnica y política son tres: el crecimiento económico vinculado al compromiso de repriorización del gasto público en salud, mejoras de las fuentes internas de recaudación a través de la reducción de la informalidad y reducción de los gastos tributarios. Con menos factibilidad se sitúa el financiamiento externo y el aumento de las contribuciones a la Seguridad Social.

Conclusiones. Bolivia está en condiciones de alcanzar un gasto público en salud de 6\% del PIB. El tiempo en que logre esta meta depende de mantener la priorización del gasto en el sector, con el consenso de la mayoría social y política y en un marco de crecimiento y estabilidad económica.

Palabras clave Financiación de la atención de la salud; política financiera; cobertura universal; recursos en salud; Bolivia.

\section{Avaliação do espaço fiscal para a saúde na Bolívia}

RESUMO Objetivo. Avaliar do ponto de vista técnico e político a capacidade da Bolívia para gerar espaço fiscal para a saúde que lhe permita sustentar o progresso e cumprir o compromisso de uma despesa de saúde pública de $6 \%$ do Produto Interno Bruto (PIB).

Métodos. Foi feita uma revisão da evidência internacional sobre o espaço fiscal e suas medições. A análise técnica foi desenvolvida através do uso de estatísticas e relatórios oficiais de múltiplas fontes secundárias nacionais e internacionais. A análise política e social foi realizada através de 20 entrevistas com representantes de organizações e instituições.

Resultados. Existe capacidade para criar espaço fiscal em saúde para a Bolívia. As fontes com maior viabilidade técnica e política são três: crescimento econômico ligado ao compromisso de desajustar as despesas públicas em saúde, melhorias nas fontes internas de receita através da redução da informalidade e redução de despesas tributárias. Com menos viabilidade é o financiamento externo e o aumento das contribuições para a Segurança Social.

Conclusões. A Bolívia é capaz de alcançar gastos de saúde pública de 6\% do PIB. O tempo que atinge esse objetivo depende da manutenção da priorização dos gastos no setor, com o consenso da maioria social e política, tudo em um quadro de crescimento econômico e estabilidade.

Palabras-chave Financiamento da assistência à saúde; política financeira; cobertura universal; recursos en saúde; Bolívia. 